\title{
Your Name
}

\begin{abstract}
ALLAN
Allan is a surname from the Old Breton baptismal name, Alan, of doubtful origin. Significations of 'all men,' 'a hound,' and 'cheerful' have been suggested, but all of these are probably only hopeful guesses. A popular Cornish or Breton Saint of the sixth century (Elian or Allan) stimulated its popularity. The name was introduced into England at the time of the Norman Conquest, notably by Alain Fergéant, Count of Brittany and Alain le Roux, first Earl of Richmond. In Domesday Book it is Alann (Norfolk). Alan has also been popular in Scotland where it has been confused with the old Gaelic name, Ailéne or Ailin. Under the spelling Allen the surname is popular all over England and is among the twenty-five most common surnames in the United States. Nathaniel Bowditch found that the surname could be spelled in 141 different ways.
\end{abstract}

\section{BRYANT}

This is an English and Irish family name from the Celtic Bryan or Brian, a hypocoristic form of bre, meaning 'hill,' with the common excrescent - $t$. From very early times Brian or Bryan has been a favorite name in Ireland on account of Brian Boraimhe, their hero king, who was slain while defeating the Danes at the battle of Clontarf, near Dublin. In the Middle Ages it was quite popular in the South of England, where it was brought in from Brittany during the Norman Conquest. After the eighteenth century the forename fell into disuse and came to be regarded as a purely Irish name. Domesday Book lists two with the name Brian. Bryant is found in the South of England while the spelling Bryan is more common in the central part.

\section{DROEGE}

A Low German family name, spelled Droog, Drooge, Droge in the Netherlands, Dröge in Germany. The word for "dry" in Dutch is "droog." "Dry" in German is "trocken." The similarity of Dutch "droog" to its umlauted dialect counterpart, and the lack thereof of German "trocken," may account for the fact that the umlaut is retained in the official written name in Germany, but only in the spoken dialect form in the Netherlands.

The family name Dröge could have been derived from a word other than "dry." Instead, it may be an etymological offshoot of proto-Germanic "dreugan," 'to endure,' 'to accomplish.' In the case of Geart B. 
Droege the anthroponym had its home in Flögeln, where everybody's last name is Dröge. This ancient Chauki settlement lies seven miles east of (East Frisian) Land Wursten. Our member and contributor belongs to the Frisian branch of the Dröges, his father having been born in Lehe, the Wurster part of Bremerhaven. In Flögeln itself the Low German Dröges have for centuries mixed with the Frisians of the Wurster Marsch.

\section{GREET}

Greet is an English name meaning 'great' or 'large,' from Middle English gret, grete, greet. Middle English grete also meant 'weeping,' but this definition undoubtedly did not enter into the formation of the surname, Greet. Chaucer used the spelling greet about the time that surnames were becoming fixed with the meaning of 'big.' Descriptive surnames referring to size are common and are found in almost all languages. When size was the most noticeable feature, a person was almost sure to acquire a nickname signifying that fact, and our member's ancestor was no exception. Surnames are only nicknames used for identification.

\section{MOFFIT}

When a man moved from the place where he was born and brought up to another locality he was likely to be identified by reference to his former home. Thus, this is a Scotch family name that refers to the man who came from Moffatt, a town in Annandale, in Dumfriesshire. In England, as one would expect, it is found chiefly in the most northern counties. Under the form Mufet the name is recorded before 1232. The place name is from Old Gaelic, locative case, mo feta, Gaelic, magh fada, meaning 'long plain,' a description of the site.

\section{SEELY}

Seely is a descriptive surname and referred originally to the happy or prosperous one, from Old English salig. The Middle English form was sely, later seely, meaning 'happy,' 'blessed,' 'simple,' 'humble,' which evolved into our modern silly, 'foolish' or 'stupid.' However, the surname seems to carry chiefly the earlier and more felicitous connotations, although the word also began to have the meaning of 'simple' or 'innocent' during the rise of English surnames. Chaucer uses the word sely more than once and always in the sense of 'good,' 'simple,' 'innocent.' The sely man, simple and unwary, was no match for those who would cheat him at every turn, and thus the world changed the meaning from sely, 'innocent,' to our modern silly. There are, of course, various spellings of the name, but this is the most common. The spellings Sealey and Sealy are confined mostly to Somersetshire in England. 


\section{TAUBE}

Taube appeared only on official documents such as birth certificates and visas. Among old-country friends and relatives the name is Duve (pronounced $d \bar{u} v$ ), which stems from the Low German of the Danzig area. The interpretation has always been 'dove.'

Throughout the ages the dove has stood for peace and innocence. It seems reasonable, then, that a person known for his mildness of manner might have this noun associated with him, so for instance the Heinrich gen- Taube Henry called Taube of a 13th century South German document. If gen. were omitted, Taube could readily develop into a family name. Dyveke of Amsterdam (ca. 1490-1517), also known as Columbula, possessed so much charm that she won the love of a Danish prince, a romance which has inspired a number of dramas and novels. Comparing a sweetheart with a dove goes back to Solomon at least. Duifke little dove was rather frequently bestowed upon Dutch girl babies at the baptismal font.

An Italian explorer, Cristoforo Colombo, has brought greatest fame to the name. In the first German work describing the discovery of America he appears as Christoffel Dawber. A particularly appropriate bearer of the name, in view of its symbolic reference to peace, was Columba, an Irish monk who labored among the South Germans during the $\eta_{\text {th }}$ century. 